\title{
NEW IN PRE-COLUMBIAN STUDIES
}

SACRIFICE,
VIOLENCE,
AND
IDEOLOGY
AMONG
THE MOCHE
THE RISE OF SOCIAL
coMpLEXIYY IANCINT PERU
STEVE BOURGET

Sacrifice, Violence, and Ideology Among the Moche

The Rise of Social Complexity in Ancient Peru

By Steve Bourget

With a comprehensive presentation of the archaeology and visual culture of a key Moche site, this pioneering book investigates why ritual violence and human sacrifice were central to the development of Moche rulership and the reinforcement of social stratification.

24 color and 442 b\&w photos, 140 b\&w illustrations $\$ 75.00$ hardcover $\bullet \$ 75.00$ e-book

"Bourget's arguments about the roles played by sacrifice, violence, and ideology will stimulate other scholars to explore how these factors may have been involved in the rise of complexity in other regions."

-Christopher B. Donnan, Emeritus of Anthropology, UCLA

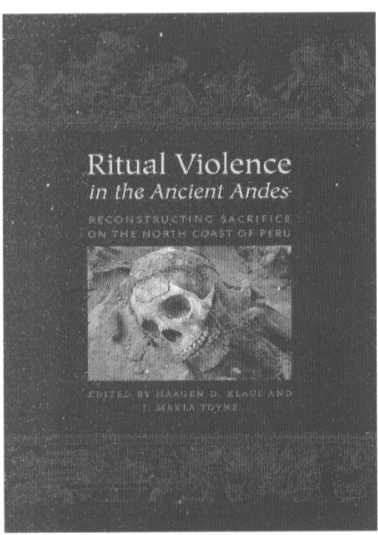

\section{Ritual Violence in the Ancient Andes}

Reconstructing Sacrifice on the North Coast of Peru Edited by HaAgen d. Klaus and J. Marla Toyne The first comprehensive synthesis of a major topic in Andean archaeology, this volume reconstructs the complex and situational motivations underlying ritual killing and the broader range of pre- and post-killing rites that were integral to ancient liturgies of violence.

92 b\&w photos, 28 illustrations

$\$ 90.00$ hardcover $\bullet \$ 34.95$ paperback $\bullet \$ 34.95$ e-book

"This volume makes a significant contribution to our understanding of ritual killings and 'sacrifice.' The contributors to develop methods, ethnographic analogies, and social theory that other scholars working outside of the Andes will find of great use." -Richard Sutter, Professor and Chair, Department of Anthropology, Indiana-PERdue UnIVERSity Fort Wayne

\section{UNIVERSITY OF TEXAS PRESS}

www.utexaspress.com

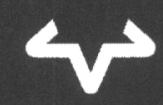

f $y$ 


\section{NOTICE TO AUTHORS}

Latin American Antiquity publishes original papers on the archaeology, prehistory, and ethnohistory of Latin America, i.e., Mesoamerica, Central America, and South America, together with culturally affiliated adjacent regions. Papers may also treat more general theoretical and methodological issues with relevance to Latin America. Authors submit manuscripts to the editor for consideration as ARTICLES or REPORTS in English, Spanish, or Portuguese. The normal, expected length of an ARTICLE will be 10-15,000 words, including bibliographies and tables. REPORTS should be under 10,000 words. Tables and illustrations should be limited to those that are appropriate and necessary. Authors are required to submit manuscripts electronically through Editorial Manager ${ }^{(h t t p: / / w w w . e d i t o r i a l m a n a g e r . c o m / l a q) . ~ D e t a i l e d ~ i n f o r m a t i o n ~ o n ~ p o l-~}$ icy, style, and technical matters of manuscript preparation is given in English and in Spanish in the "Editorial Policy. Information for Authors, and Style Guide for American Antiquity and Latin American Antiquity," available through the World Wide Web at http://www.saa.org/ Publications/StyleGuide/styframe.html. For additional information, updates, or clarification, consult the managing editor at the SAA office in Washington, D.C.

\section{BOARD OF DIRECTORS OF THE SOCIETY FOR AMERICAN ARCHAEOLOGY}

\section{Officers}

President: DIANE GIFFORD-GONZALEZ, Anthropology Department, University of California, Santa Cruz, CA 95064

Secretary: PATRICIA A. GILMAN, Department of Anthropology, University of Oklahoma, Norman, OK 73019

Treasurer: JIM BRUSETH, Ph.D., Bullock Texas State History Museum, 6806 Rio Bravo Lane, Austin, TX 78737

Treasurer-elect: DEBORAH L. NICHOLS, Dartmouth College, Department of Anthropology, Hanover, NH 03755

\section{Board Members at-Large}

S. TERRY CHILDS, Department of the Intcrior, Office of Acquisition \& Property Management, DOI Museum Program, Washington, DC 20240-0001

CHIP COLWELL-CHANTHAPHONH, Denver Museum of Nature \& Science, Department of Anthropology, 2001 Colorado Boulevard, Denver, CO 80205-5798

JOHN G. DOUGLASS, RPA, Statistical Research, Inc., PO Box 31865, Tucson, AZ 85751

RODRIGO LIENDO, Universidad Nacional Autónoma de México, Instituto de Investigaciones Antropológicas. Ciudad Universitaria, MÉX 045I0 Mexico

GORDON F.M. RAKITA, Ph.D., RPA, University of North Florida, Department of Sociology and Anthropology, 1 UNF Drive, Building 51, Room 2304, Jacksonville, FL 32224

DANIEL H. SANDWEISS, University of Maine, Anthropology Department, South Stevens Hall, Orono, ME 04469

\section{Ex-Officio Board Member}

TOBI A. BRIMSEK, Executive Director, Society for American Archaeology. 1111 14th Street NW, Suite 800. Washington, DC 20005 


\section{ARTICLES}

3 Early Prehistoric Maize in Northern Highland Ecuador

J. Stephen Athens, Jerome V. Ward, Deborah M. Pearsall, Karol Chandler-Ezell, Dean W. Blinn, and Alex E. Morrison

Ecuadorian Cinnabar and the Prehispanic Trade in Vermilion Pigment: Viable Hypothesis or Red Herring? Richard L. Burger, Kris E. Lane, and Colin A. Cooke

La Comercialización del Patrimonio Arqueológico-Numismático Sumergido: Reflexiones en Torno al Criterio de Monedas Repetidas y Otros Anacronismos

Nicolás C. Ciarlo

51 The Use of Firewood in Ancient Maya Funerary Rituals: A Case Study from Rio Bec (Campeche, Mexico) Lydie Dussol, Michelle Elliott, Grégory Pereira, and Dominique Michelet

Ritual Diversity and Divergence of Classic Maya Dynastic Traditions: A Lexical Perspective on Within-Group Cultural Variation

Jessica Munson, Jonathan Scholnick, Matthew Looper, Yuriy Polyukhovych, and Martha J. Macri

El Indígeno and High-Altitude Human Occupation in the Southern Andes, Mendoza (Argentina) Gustavo Neme

115 Huancas and Rituals of Fertility in the Farming Landscape of the Northern Calchaquí Valley (Salta, Argentina) María Cecilia Páez and Gimena Alé Marinangeli

\section{REVIEWS}

\section{Maya Cities and Villages}

Ancient Maya Cities of the Eastern Lowlands, by Brett A. Houk, and Community and Difference:

Change in Late Classic Maya Villages of the Petexbatun Region, by Markus Eberl

Keith Eppich

134 The Evolution of Ceramic Production Organization in a Maya Community, by Dean E. Arnold Antonia E. Foias

135 Tenahaha and the Wari State: A View of the Middle Horizon from the Cotahuasi Valley, edited by Justin Jennings and Willy Yépez Álvarez

Véronique Bélisle

136 Maya Figurines: Intersections between State and Household, by Christina T. Halperin

Rosemary A. Joyce

138 Formative Lifeways in Central Tlaxcala, Volume 1: Excavations, Ceramics, and Chronology, edited by Richard G. Lesure

Robert M. Rosenswig

139 The Inka Empire: A Multidisciplinary Approach, edited by Izumi Shimada John R. Topic

140 Archaeology and Bioarchaeology of Population Movement among the Prehispanic Maya, edited by Andrea Cucina Rebecca Storey

141 The Maya, by Michael Coe and Stephen Houston

Jaroslaw Zralka

On the Cover: Gold mask painted with cinnabar pigment that covered the detached head of the principal personage of the Huaca Loro East Tomb excavated during the 1991-1992 season of the Sipán Archaeological Project (photograph courtesy of the Sican Archaeological Project and Yutaka Yoshii, copyright Yutaka Yoshii and Izumi Shimada) From "Ecuadorian Cinnabar and the Prehispanic Trade in Vermilion Pigment: Viable Hypothesis or Red Herring?" by Richard L. Burger, Kris E. Lane, and Colin A. Cooke, page 24. 